\title{
Efficacy and Safety of Thalidomide as Adjunct Therapy in Refractory Systemic Juvenile Idiopathic Arthritis Patients
}

\author{
Islam MM ${ }^{1}$, Islam $\mathrm{MI}^{1}$, Talukdar $\mathrm{MK}^{1}$, Haque $\mathrm{M}^{1}$, Rahman $\mathrm{SA}^{1}$ \\ ${ }^{I}$ Department of Paediatrics, Bangabandhu Sheikh Mujib Medical University, Dhaka, Bangladesh \\ e-mail: mahbub25somc@gmail.com
}

\begin{abstract}
About $50 \%$ of systemic onset juvenile idiopathic arthritis (sJIA) patients run a recalcitrant disease course and resistant to the conventional disease modifying anti inflammatoy drugs (DMARDs), ultimately resulting in permanent disability from joint destructions. Thalidomide has been reported as an effective and safe drug in the management of systemic JIA due to its immunomodulatory properties. This was an interventional study, aimed to evaluate the efficacy of thalidomide in refractory JIA patients. Twenty five systemic JIA patients who were refractory to conventional DMARDs were included in this study. These patients were prescribed thalidomide at a dose of $2-3 \mathrm{mg} / \mathrm{kg} / \mathrm{day}$ for 12 months. Efficacy of thalidomide was assessed by using Wallace criteria at $6^{\text {th }}$ month and $12^{\text {th }}$ month of thalidomide treatment. Active arthritis was improved in 55\% and $73 \%$ of the patients at $6^{\text {th }}$ and $12^{\text {th }}$ month of thalidomide treatment respectively. Fever and rash subsided in $72.8 \%$ and $81.2 \%$ of patients respectively at $12^{\text {th }}$ month of follow up. Hepatosplenomegaly and lymphadenopathy regressed in $100 \%$ of patients at $12^{\text {th }}$ month follow up. ESR was also improved in $50 \%$ and $68.2 \%$ cases at $6^{\text {th }}$ and $12^{\text {th }}$ months respectively. Few minor side effects were observed like transient elevation of liver enzyme and somnolence in this study. It may be concluded that thalidomide is safe and effective in refractory JIA patients.
\end{abstract}

Keywords: Juvenile idiopathic arthritis, Thalidomide, Refractory, Safety, Efficacy

\section{Introduction}

Juvenile idiopathic arthritis (JIA) is the most common rheumatic disease of children and is a very important cause of short and long term morbidity and disability. ${ }^{1}$ It is characterized by idiopathic peripheral arthritis with an immunoinflammatory pathogenesis possibly activated by contact with external antigens. ${ }^{2}$

It is classified into seven subgroups according to International league of associations for rheumatology (ILAR) 2001 classification. ${ }^{3}$ Systemic onset JIA (sJIA) is one of the seven subtypes, incidence of which was found in 10- $20 \%$ cases. $^{4}$ Recently, a study done in Bangladesh found that $14 \%$ of patients had sJIA in their study.5 Besides, an Indian and a Canadian study found 7.7 and $4.4 \%$ of sJIA patients respectively in their series. ${ }^{6,7}$ Systemic JIA has 2$4 \%$ overall mortality rate and accounts for two third of all deaths among children with arthritis. About $50 \%$ of these patients run a recalcitrant disease course and resistant to the conventional disease modifying anti rheumatic drugs (DMARDs), ultimately resulting in permanent disability from joint destructions and local growth deformities. $^{8}$

Thalidomide is a unique anti-inflammatory agent that suppresses angiogenesis, cellular adhesion molecule expression and production of tumor necrosis factor- $\alpha$ and interleukin- 6 . It also inhibits leucocyte chemotaxis and decrease the CD4/CD8 ratio. ${ }^{9}$ Thalidomide, once discarded as a potent teratogen, has been reported effective in the management of sJIA due to its immune modulatory properties. ${ }^{10}$ Sedation, somnolence, myalgia, constipation, neutropenia and anaphylaxis were found as common side effects of thalidomide therapy in different studies. ${ }^{10,6}$ Till date, so far no study has been done on efficacy of thalidomide therapy in refractory sJIA patients in Bangladesh. The aim of this study was to evaluate the efficacy of thalidomide in refractory sJIA patients. 


\section{Materials and Methods}

This was an interventional study carried out in the Paediatric Rheumatology follow-up clinic run by the Department of Pediatrics, Bangabandhu Sheikh Mujib Medical University (BSMMU), Dhaka from July 2013 to December 2014. There were 72 sJIA patients, who were registered in the paediatric rheumatology follow up clinic during study period. Amongst them, 25 were identified as refractory sJIA patients, and were enrolled in the current study. Three patients did not complete their regular follow-up visit, and were subsequently excluded from the study.

After obtaining informed consent from patients/parents, data were collected in a questionnaire. The data included demographic information, detailed history, physical examination and laboratory findings including CBC with ESR, serum aminotransferase and serum creatinine.

The study subjects were administered methotrexate (MTX) by sub cutaenous route at a dose $15 \mathrm{mg} / \mathrm{m}^{2}$ body surface area/week for at least 6 months along with steroid (starting at 0.5 to 1 $\mathrm{mg} / \mathrm{kg} /$ day and gradually tappering dose). As no satisfactory improvement occured, hydroxychloroquine at a dose of 5 to $6 \mathrm{mg} / \mathrm{kg} /$ day was added for another 3 months.

Working definition of Refractory sJIA patients who were treated with two conventional DMARDs in appropriate dose along with other adjuvant therapy for at least 6 months and failed to achive a remission according to Wallace criteria $^{11}$ were considered as refractory SJIA patient. Subsequently these patients were prescribed thalidomide at a dose of $2-3 \mathrm{mg} / \mathrm{kg} / \mathrm{day}$ for 12 months. Methotrexate and hydroxychloroquine were also continued during this period. Efficacy of thalidomide was assessed by using Wallace criteria ${ }^{11}$ at $6^{\text {th }}$ month and $12^{\text {th }}$ month of thalidomide treatment. At the same time adverse events of thalidomide if any were also looked for. For statistical analysis, Chi-square and paired t-test were done for qualitative and quantitative data respectively.

\section{Results}

A total of 22 patients completed the study. Amongst them, $82 \%$ were male and $18 \%$ were female, M: F ratio was 5.25:1. Age range of the patients was 5.5 year to 15 year and most of the patients were in the age group of 6-10 year. Disease duration at presentation was more than 12 months in the majority (68\%) of cases. The mean dose of steroid was $0.635 \pm 0.123 \mathrm{mg} / \mathrm{kg}$ at the beginning of the study (table I).

Table I: Baseline demography of cases $(\mathrm{n}=25)$

\begin{tabular}{|c|c|c|}
\hline Demographic characteristics & Frequency & Percentage $(\%)$ \\
\hline \multicolumn{3}{|l|}{ Age } \\
\hline $0-5$ yrs & 5 & 20.0 \\
\hline $6-10 \mathrm{yrs}$ & 13 & 52.0 \\
\hline $11-15 \mathrm{yrs}$ & 7 & 28.0 \\
\hline Total & 25 & 100.0 \\
\hline \multicolumn{3}{|l|}{ Sex } \\
\hline Male & 21 & 84.0 \\
\hline Female & 4 & 16.0 \\
\hline $\begin{array}{l}\text { Age at disease onset (years) } \\
\text { (mean } \pm \text { SD) }\end{array}$ & \multicolumn{2}{|c|}{$5.50 \pm 2.37$} \\
\hline $\begin{array}{l}\text { Age at diagnosis (years) } \\
(\text { mean } \pm \text { SD) }\end{array}$ & \multicolumn{2}{|c|}{$6.54 \pm 2.58$} \\
\hline Disease duration (years) & & \\
\hline $1-3 \mathrm{yrs}$ & 17 & 68.0 \\
\hline $4-6 \mathrm{yrs}$ & 7 & 28.0 \\
\hline $7-9$ yrs & 1 & 4.0 \\
\hline \multicolumn{3}{|l|}{ Treatment history } \\
\hline MTX & 25 & $100 \%$ \\
\hline Hydroxychloroquine & 25 & $100 \%$ \\
\hline $\begin{array}{l}\text { Prednisolone dose } \\
(\text { mean } \pm \text { SD })\end{array}$ & $0.635 \pm 0.123$ & \\
\hline
\end{tabular}

All patients presented with fever. Other systemic features like rash were found in $92 \%$ of patients, lymphadenopathy and hepatomegaly were found in $84 \%$ and $92 \%$ of patients respectively (table II).

Table II: Baseline Disease Activity ( $\mathrm{n}=25)$

\begin{tabular}{lcc}
\hline \multicolumn{1}{c}{ Baseline } & Frequency & Percentage (\%) \\
\hline $\begin{array}{l}\text { Presence of systemic } \\
\text { features }\end{array}$ & & \\
Fever & 25 & $100.0 \%$ \\
Rash & 23 & $92.0 \%$ \\
Lymphadenopathy & 21 & $84.0 \%$ \\
Hepatomegaly & 23 & $92.0 \%$ \\
Splenomegaly & 20 & $80.0 \%$ \\
Serositis & 3 & $12.0 \%$ \\
\hline
\end{tabular}

At presentation, active arthritis was present in $100 \%$ of patients. ESR was high in $84 \%$ patients and mean physician assessment of global disease activity was $7.99 \pm 0.71$ (table III). 
Table III: Baseline Lab Parameters ( $\mathrm{n}=25)$

\begin{tabular}{lcc}
\hline Lab parameters: & Range & Mean \pm SD \\
\hline $\mathrm{Hb}(\%)$ & $5.7-11.4$ & $9.04 \pm 1.38$ \\
$\mathrm{ESR}$ & $4.0-180.0$ & $76.74 \pm 42.15$ \\
Platelet & $180.0-850.0$ & $553.70 \pm 173.09$ \\
Total count & $5.0-35.0$ & $15.20 \pm 7.00$ \\
Neutrophil & $52.0-84.0$ & $70.48 \pm 7.82$ \\
ALT & $16.0-176.0$ & $47.96 \pm 46.55$ \\
Serum Creatinine & $0.30-0.90$ & $0.57 \pm 0.14$ \\
\hline
\end{tabular}

At 6 month of follow-up, active arthritis was improved in $55 \%$ of the patients $(p<0.001)$ and ESR was improved in $50 \%$ cases $(p<0.006)$. While considering systemic features like fever and rash, $59.1 \%$ and $68.2 \%$ patients became fever and rash free respectively and lymphadenopathy disappeared in $100 \%$ of patients. Hepatomegaly and splenomegaly disappeared in $72.73 \%$ and $68.2 \%$ patients respectively in this series ( $p$ $<0.05)$.

Table IV: Improvement According to Wallace Criteria from Baseline to Follow up $(n=25)$

\begin{tabular}{|c|c|c|c|c|c|}
\hline \multirow{2}{*}{ Variables } & \multirow{2}{*}{$\underset{(\mathbf{n}=\mathbf{2 5})}{\text { Baseline }}$} & \multirow{2}{*}{$\begin{array}{c}\text { At } 6 \\
\text { months } \\
(\mathrm{n}=22)\end{array}$} & \multirow{2}{*}{$\begin{array}{c}\text { At } 12 \\
\text { months } \\
(\mathrm{n}=22)\end{array}$} & \multicolumn{2}{|c|}{ p value } \\
\hline & & & & $\begin{array}{c}\text { Baseline } \\
\frac{\text { Vs. }}{6 \mathrm{~m}}\end{array}$ & $\begin{array}{l}\text { Baseline } \\
\text { Vs. } 12 \mathrm{~m}\end{array}$ \\
\hline $\begin{array}{l}\text { Number of } \\
\text { patients with } \\
\text { active arthritis }\end{array}$ & $\begin{array}{c}25(100.0 \\
\%)\end{array}$ & $\begin{array}{c}10(45.4 \\
5 \%)\end{array}$ & $6(27 \%)$ & $<0.001$ & $<0.001$ \\
\hline \multicolumn{6}{|c|}{ Presence of systemic Features: } \\
\hline Fever & $\begin{array}{c}25(100 \\
.0 \%)\end{array}$ & $\begin{array}{c}9(40 . \\
9 \%)\end{array}$ & $\begin{array}{c}6(27.2 \\
7 \%)\end{array}$ & $<0.001$ & $<0.001$ \\
\hline Rash & $\begin{array}{c}23(92 \\
\%)\end{array}$ & $\begin{array}{l}7(31 . \\
8 \%)\end{array}$ & $\begin{array}{c}4(18.1 \\
8 \%)\end{array}$ & $<0.001$ & $<0.001$ \\
\hline $\begin{array}{l}\text { Lymphadenop } \\
\text { athy }\end{array}$ & $\begin{array}{c}21(84 \\
\%)\end{array}$ & 0 & 0 & $<0.001$ & $<0.001$ \\
\hline $\begin{array}{l}\text { Hepatomegal } \\
\text { y }\end{array}$ & $\begin{array}{c}23(92 \\
\%)\end{array}$ & $\begin{array}{l}6(27 . \\
27 \%)\end{array}$ & 0 & $<0.001$ & $<0.001$ \\
\hline Splenomegaly & $\begin{array}{c}20(80 \\
\%)\end{array}$ & $\begin{array}{l}7(31 . \\
8 \%)\end{array}$ & 0 & 0.004 & $<0.001$ \\
\hline Serositis & $\begin{array}{c}3(12.0 \\
\%)\end{array}$ & 0 & 0 & 0.233 & 0.233 \\
\hline $\begin{array}{l}\mathrm{ESR}^{*}>20 \\
\left(\mathrm{~mm} \text { in } 1^{\text {sthr }}\right) \\
\text { Physician's }\end{array}$ & $\begin{array}{c}21(84 \\
\%)\end{array}$ & $\begin{array}{c}11(50 \\
.0 \%)\end{array}$ & $\begin{array}{c}7(31.8 \\
\%)\end{array}$ & 0.006 & $<0.001$ \\
\hline $\begin{array}{l}\text { Visual } \\
\text { Analogue } \\
\text { Scale } \\
\text { Mean } \pm \mathrm{SD}^{\#}\end{array}$ & $\begin{array}{l}7.99 \pm 0 \\
.71\end{array}$ & $\begin{array}{c}4.35 \pm \\
1.92\end{array}$ & $\begin{array}{c}1.30 \pm 1 \\
56\end{array}$ & $<0.001$ & $<0.001$ \\
\hline $\begin{array}{l}\text { Number of } \\
\text { patients with } \\
\text { active disease } \\
\text { Prednisolone }\end{array}$ & $\begin{array}{c}25(100 \\
.0 \%)\end{array}$ & $\begin{array}{c}14(63 \\
.6 \%)\end{array}$ & $\begin{array}{c}9(40.9 \\
\%)\end{array}$ & 0.004 & $<0.001$ \\
\hline $\begin{array}{l}\text { Prednisolone } \\
(\mathrm{mg} / \mathrm{kg}) \\
(\mathrm{mean}+\mathrm{SD})^{\#}\end{array}$ & $\begin{array}{l}0.625 \pm \\
0.125\end{array}$ & $\begin{array}{c}0.485 \\
\pm 0.14 \\
2\end{array}$ & $\begin{array}{c}0.412 \pm \\
0.119\end{array}$ & 0.07 & $<0.001$ \\
\hline
\end{tabular}

At 12 month follow-up, 73\% improvement was found in active arthritis, $68.2 \%$ improvement in ESR and $59.1 \%$ in disease activity. While considering systemic features, $72.8 \%$, and $81.2 \%$ patients became fever and rash free respectively. Hepatosplenomegaly were regressed in all the patients at $12^{\text {th }}$ month of treatment $(p<0.001)$. It was possible to taper the dose of steroid during follow up at 6 month and 12 month but significant reduction was possible at 12 month (table IV).

\section{Discussion}

Systemic arthritis has a variable disease course. Among about the half of the patients, the disease is characterized by monocyclic or intermittent course with relapses followed by remission. Remaining half of the patients, the disease follows an unremitting course. ${ }^{11}$ Persistently active systemic JIA represents a major challenge to paediatric rheumatologists. Traditional diseasemodifying anti-rheumatic drugs have limited benefit in this type of JIA. ${ }^{12}$ In a study, thalidomide was shown efficacious for treating refractory sJIA. ${ }^{10}$ The present study have also shown the efficacy of thalidomide therapy in 22 patients who were nonresponsive to traditional DMARDs. Before starting thalidomide they were offered biological therapy, but due to economic constraint they could not afford that. Boys and girls ratio was 5.25: 1 which was different from other established study ${ }^{9}$ where boys and girls ratio was nearly $1: 1$. This may be due to the fact that boys get more preference and attention by the male dominating society in Bangladesh and are taken to health service facilities early. Another study from Bangladesh also showed similar findings where M:F ratio among JIA patients were $2: 1 .^{13}$

The number of patients with active arthritis were significantly improved at $6^{\text {th }}$ month $(54.55 \%)$ and $12^{\text {th }}$ month (73\%) of follow-up when compared with time of enrollment $(p<0.001)$. Systemic features like fever, rash, lymphadenopathy, hepatosplenomegaly were also significantly improved in this study. Normalisation of acute phase reactant (ESR) was found in $68.2 \%$ cases. These findings were almost similar with Lehman et al's results. ${ }^{10}$ García-Carrasco et al reported three cases of recalcitrant sJIA that improved dramatically after treatment with thalidomide. ${ }^{14}$ An Indian study with three children with refractory sJIA also reported improvement after treatment with thalidomide. ${ }^{6}$

Dose of steroid was reduced significantly in this study and two of our patients were able to discontinue prednisolone, whereas 6 (out of 13) patients were able to discontinue prednisolone in Lehman et al study. ${ }^{10}$ The difference may be explained by the facts that, perhaps severity of the disease at presentation might have been different 
in this study. Delay in diagnosis and treatment before seeking medical services might have also influenced the outcome.

Thalidomide is a well-known teratogen which was withdrawn from market in $196^{15}$ but this risk is not a problem in this study population. Tolerability of thalidomide is generally found to be better with single night time administration. Thalidomide is a cheap and available drug in comparison to other biological agents. ${ }^{6}$

Common side effects in this study included transient elevation of aminotransferase in two cases and somnolence in three cases. Short lived paresthesia (tingling, numbness) were found during initial period of therapy in another study. ${ }^{10}$ No neurotoxicity amongst the cases of this study was to be found though in literature neurotoxicity/ paraesthesia is commonly found. ${ }^{1}$

\section{Conclusion}

Beneficial effects of thalidomide in sJIA patients as adjunct therapy were found in this study amongst the patients, who were non responsive to traditional DMARDs. So, it may be concluded from this study that thalidomide may be used in children with sJIA who have failed to conventional therapy. Though the adverse effects of this drug were minimal, use of this drug in children should be carefully supervised.

\section{References}

1. Jennifer EW, Norman TI. Juvenile Idiopathic Arthritis. Pediatr Clin N Am. 2005; 52: 413-28.

2. Bukulmez H, Murray H, William SR. Classification of Juvenile chronic idiopathic arthropathies: Is it time to change yet? Bulletin on the Rheumatic Disease 2003;51: 1-5.

3. Cassidy JT, Petty RE. Chronic Arthritis in Childhood. In: Cassidy JT, Petty RE, Laxer RM, Lindsley CB, (editors). Textbook of Pediatric Rheumatology; $6^{\text {th }}$ edn Saunders, Philadelphia; 2005. p 211-35.

4. Eveline Y, Heather A, Mater V and Robinovich, CE .Juvenile Idiopathic Arthritis, In Kliegman RM, Stanton BF, Schor NF, Behrman RE and Geme JW, editors, Nelson Textbook of Pediatrics; $19^{\text {th }}$ edn. Elsevier, Philadelphia. 2012. p 829- 39.

5. Islam MI, Talukder MK, Rahman SA. Pattern of Paediatric Rheumatic Diseases: Experience from a Tertiary Care Hospital, Dhaka, Bangladesh. Bangladesh Journal of Child Health. 2013; 37: 97101.

6. Sathe K, KhubchandaniRP Thalidomide for Systemic Onset Juvenile idiopathic arthritis. Indian Padiatrics. 2013; 50: 237-39.

7. Kunjir V, Venugopalan A, Chopra A. Profile of Indian Patients with Juvenile Onset Chronic Inflammatory Joint Disease Using the ILAR classification criteria for JIA: A community based Cohort study. The Journal of Rheumatology. 2010; 37:1756-62.

8. Hayward K, Wallace CA (2009) recent developments in anti rheumatic drugs in paediatrics: treatment of juvenile idiopathic arthritis. Arthritis Res Ther. 2009; 11; 216.

9. Lehman TJA, Striegel KH and Onel KB. Thalidomide therapy for recalcitrant systemic onset juvenile rheumatoid arthritis. J Paediatr. 2002; 140; 125-27.

10. Lehman TJA, Schechter SJ, Sundel RP. Thalidomide for severe systemic onset juvenile rheumatoid arthritis: a multicenter study. J Paediatr. 2004 ; 145: 856-57.

11. Wallace CA, Ruperto N and Giannini H Preliminary criteria for clinical remission for select categories of juvenile idiopathic arthritis. J Rheumatol. 2004; 31:2290-94.

12. Ravelli A, Martini A. Juvenile idiopathic arthritis. Lancet. 2007; 369:767-78.

13. Rahman SA, Islam MI and Talukder MK. Clinical aspects of juvenile idiopathic arthritis: extended experience from Bangladesh. American Journal of Clinical and Experimental Medicine. 2013; 1: 20-23.

14. García CM, Fuentes AS, Escárcega RO. Efficacy of thalidomide in systemic onset juvenile rheumatoid arthritis. Joint Bone Spine. 2007; 74; 500-3.

15. Miller MT, Stromland K.Teratogen Update: Thalidomide: A Review, with a Focus on Ocular Findings and New Potential Uses. Teratology. 1999; 60: 306-21 